\title{
Distal Bile Duct Cancer pN1 TNM Finding v8
}

National Cancer Institute

\section{Source}

National Cancer Institute. Distal Bile Duct CancerpN1 TNM Finding v8. NCI Thesaurus.

Code C134808.

Distal bile duct cancer with metastasis in one to three regional lymph nodes. (from AJCC 8th Ed.) 